\title{
EVALUATION OF EFFECTIVE PARAMETERS OF BIOMASS HEAT TREATMENT IN PROCESSING FOR SOLID FUEL
}

\author{
Serhii Yermakov ${ }^{1}$, Taras Hutsol ${ }^{1}$, Anna Rozkosz ${ }^{2}$, Szymon Glowacki ${ }^{3}$, Sergii Slobodian ${ }^{1}$ \\ ${ }^{1}$ State Agrarian and Engineering University in Podillia, Ukraine; \\ ${ }^{2}$ Qualia Lab Sp zoo oraz Fundacja Qualia, Poland; ${ }^{3}$ Warsaw University of Life Sciences, Poland \\ ermkov@gmail.com,pro-gp@pdatu.edu.ua,dakgps@pdatu.edu.ua
}

\begin{abstract}
The fuel and energy crisis and the increasing pollution of the environment are one of the pressing problems facing humanity today. In this regard, the question of finding new alternative energy sources is urgent. Today there is an increasing interest in solid biofuels and new methods for improving the properties of biofuels are being developed and improved, such as grinding, drying, pressing, and more recently, heat treatment. Thermal methods of impact on biomass require special attention of researchers, because while their consumption consumes some energy, it leads to an increase in the cost of production. But at the same time, they allow not only to increase the specific energy characteristics of biofuels by removing moisture and ballast components, but also to obtain fuel with new useful features (such as hydrophobicity, low greenhouse gas emissions, diminishing smoke and odours, no corrosive substances). Depending on the biomass heat treatment modes, a different end product can be obtained, and changes in it can be estimated by the weight loss. Investigations of this process were carried out in the educational scientific laboratory "DAK GPS" of the State Agrarian and Engineering University in Podilya at the plant for the torrefaction of tape-type biomass with passive interaction with the material. Control automatics allow to adjust and maintain the temperature in the thermal chamber, as well as the speed of movement of the tape, which determines the residence time of the biomass under the influence of thermal action. During each 10-minute heat treatment cycle in $20{ }^{\circ} \mathrm{C}$ increments, mass loss was determined, and additional factors were recorded that could indicate the beginning of internal changes in the material being studied (smoke, odour, etc.). As a result, the conducted research proved that the torrefaction process of different raw materials meets its own temperature range, in which there are active changes of material, namely converts raw biomass into torrefied product. This range for the studied samples is $40-50{ }^{\circ} \mathrm{C}$, in particular for barley and soybeans the process of torrefaction begins at 185 $195^{\circ} \mathrm{C}$ and ends at $230-240{ }^{\circ} \mathrm{C}$, for poplar, willow and miscanthus these figures are respectively $235-245^{\circ} \mathrm{C}$ and 280-300 ${ }^{\circ} \mathrm{C}$. As shown by the studies, for most biomaterials of plant origin we can distinguish the beginning of intensive transformation and its end, after which there is a sharp slowdown in the weight loss, and accordingly, in the energy density of the samples.
\end{abstract}

Keywords: biomass, biofuel, torrefaction, torrefied product, colour change.

\section{Introduction}

The fuel and energy crisis and the increasing pollution of the environment are one of the pressing problems facing humanity today. In this regard, the question of finding new alternative energy sources is urgent. Such a search is often supported by various government programs [1] and accompanied by the emergence of new types of management, and the development of new technical means for implementation [2-5]. In Ukraine, bioenergy has gained the greatest development and distribution thanks to an affordable and cheap raw material base, the lion's share of which is woodworking, logging and woodworking waste (bark, sawdust, chips), peat and agricultural waste (straw, sunflower husk, cereals, waste production, etc.). However, due to the different dispersion, low energy content, low bulk density and usually high moisture content in such materials, their direct use is limited mainly to internal use within the enterprise. In addition, the issue of reducing the burden on the environment due to the combustion of various fuels is increasingly being raised. Therefore, the issue of reducing greenhouse gas emissions and the release of other combustion by-products should be resolved in parallel. In this regard new methods for improving the properties of biofuels are being developed and improved, such as grinding, drying, pressing, etc. For today, one of the most effective methods to increase the efficiency of solid fuels is pre-torrefaction - thermal treatment without access to oxygen [6]. The applications of torrefaction and upgraded biomass have been discussed in some papers [7-13]. However, the information on the system integration and practical applications of biomass torrefaction in the industry remains insufficient.

Thermal methods of impact on biomass require special attention of researchers, because while their consumption consumes some energy, it leads to an increase in the cost of production, but at the same time they allow not only to increase the specific energy characteristics of biofuels by removing moisture and ballast components, but also to obtain fuel with new useful features (such as hydrophobicity, low 
greenhouse gas emissions, diminishing smoke and odours, no corrosive substances) [12]. Upon examining the articles, similar research focus can be observed, such as torrefaction effects on biomass properties, energy densification, and solid and energy yields, followed by addressing the industrial, environmental, and agricultural applications of torrefied biomass ,such as combustion, ironmaking, pyrolysis, liquefaction, gasification, pollutant adsorption, and soil amendment $[7 ; 10 ; 11 ; 15 ; 16]$. Several studies attempted to understand biomass thermal degradation behaviours by conducting torrefaction kinetics [17-20]. The thermogravimetric method of analysis is widely used to study the torrefaction process. This method allows not only to obtain quantitative characteristics of the process of term decomposition, but also to describe this process with sufficient accuracy in the form of kinetic equations [21]. Although such studies are the most accurate, they are not so common in the literature [22], which is due to the high complexity of the experiments and the need to have the appropriate equipment.

For production conditions it is important, first of all, to have qualitative characteristics of the final product, which depend on the modes of thermal processing of biomass. This is due to the fact that in the process of torrefaction there is not only removal of moisture from the raw material (drying), but also partial thermal destruction of the organic component of biomass. It is accompanied by changes that can be detected and evaluated not only by complex laboratory analysis, but also by simple measurements, weighing or even organoleptic evaluation of samples. According to the parameters that characterize the level of thermal transformations of biomass can be a change in colour, weight loss, change in the shape and size, acquisition of new properties (fragility, hardness, etc.). The aim of the work is to identify qualitative and quantitative characteristics of such parameters of the initial assessment of the process as the weight loss and colour change.

\section{Materials and methods}

It continues the work on the scientific topic "Agrobiomass of Ukraine as an energy potential of Central and Eastern Europe" (registration number 0119U103056) at the State Agrarian and Engineering University in Podilia, the joint Ukrainian-Polish educational and scientific laboratory "DAK GPS" [2327]. The main activity of the laboratory is to improve the energy performance of biomass by thermal treatment (torrefaction), which results in torrefied product. Investigations of the primary signs of the state of heat-treated raw materials were carried out on a plant for torrefaction of tape-type biomass with passive interaction with the material (Fig.1). This method minimizes the physical and mechanical effects on the raw material, and the flow of the process allows to get the most homogeneously processed product. Control automatics allow to adjust and maintain the temperature in the thermal chamber, as well as the speed of movement of the tape, which determines the residence time of the biomass under the influence of thermal action.
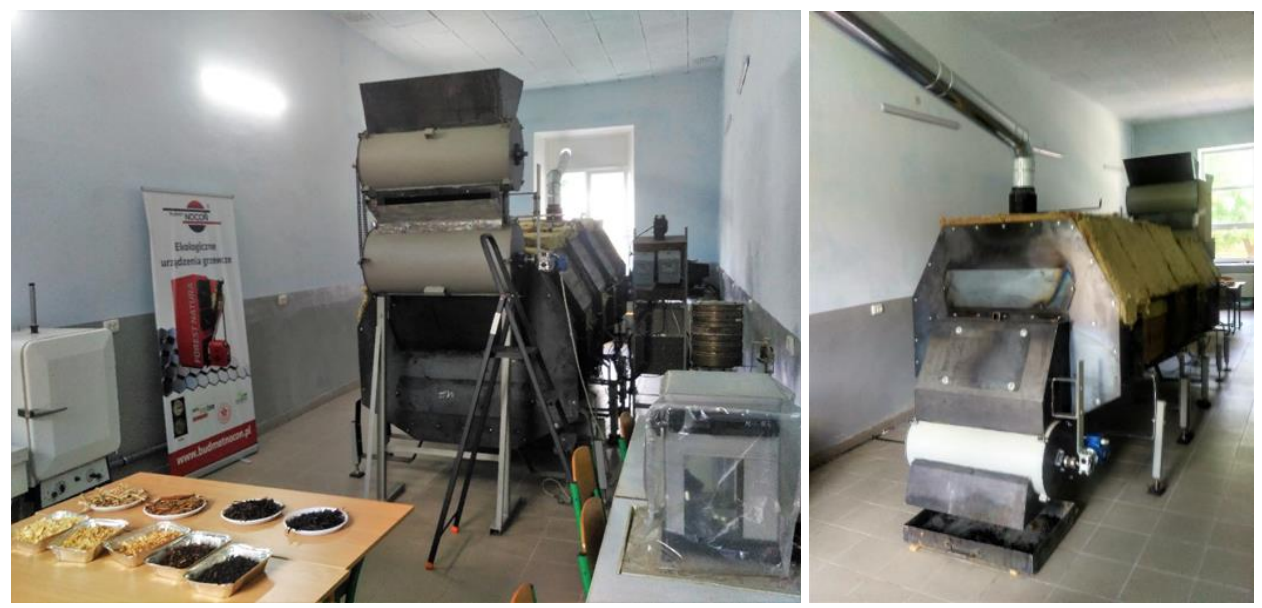

Fig. 1. General view of the biomass torrefaction installation (in laboratory "DAK GPS")

Selected biomass samples using laboratory scales were divided into equal-weight portions of 50$100 \mathrm{~g}$, which were alternately subjected to thermal treatment with a step of $20 \mathrm{C}$ in the range of 180 $300{ }^{\circ} \mathrm{C}$, which fully corresponds to the conditions of torrefaction. After thermal treatment, organoleptic evaluation of the product was performed, and the final weight was recorded. 


\section{Results and discussion}

Given the new qualitative properties that raw materials acquire as a result of such processing, the process of biomass torrefaction is actively studied by scientists around the world. Various studies of the process have appeared. Thus, studies of changes in the specific heat of combustion of such fuel, the limits of hygroscopicity of the obtained product, the study of destruction of organic matter, determination of the quantitative and qualitative composition of decomposition products, and so on [6; $14 ; 21-22 ; 28-30]$. At the same time special techniques and equipment, which allows to reveal these or those indicators, are usually applied. Perhaps, the main criterion that characterizes the quality of the product is its specific heat of combustion. For some types of raw materials this figure is known, but thermal treatment makes its adjustments, because it reduces the weight of the material, and the energy density, respectively, increases. Analysis of the kinetics of drying and thermal treatment of some types of biomass is considered in the works of Zaichenko, Maryandyshev, Lyubov [14; 21;28]. They show thermogravimetric curves of the mass change dynamics (TG), mass change rate (DTG) and thermal effects that occur in the test sample depending on the mode of torrefaction and the type of raw material.

On such curves it is usually possible to allocate two peaks. The first one corresponds to the phase of active removal of physical and mechanical moisture and is limited by the rate of external diffusion of moisture. This is the process of drying the material. The second peak corresponds directly to torrefaction and is determined by the nature of the destruction of organic and inorganic components of raw materials and the removal of volatile substances from it. This peak is of the greatest interest, because this parameter characterizes the quality of the final product - torrefied biomass.

To determine these parameters a number of studies were conducted for different types of raw materials, the results of which are shown in Fig. 2.

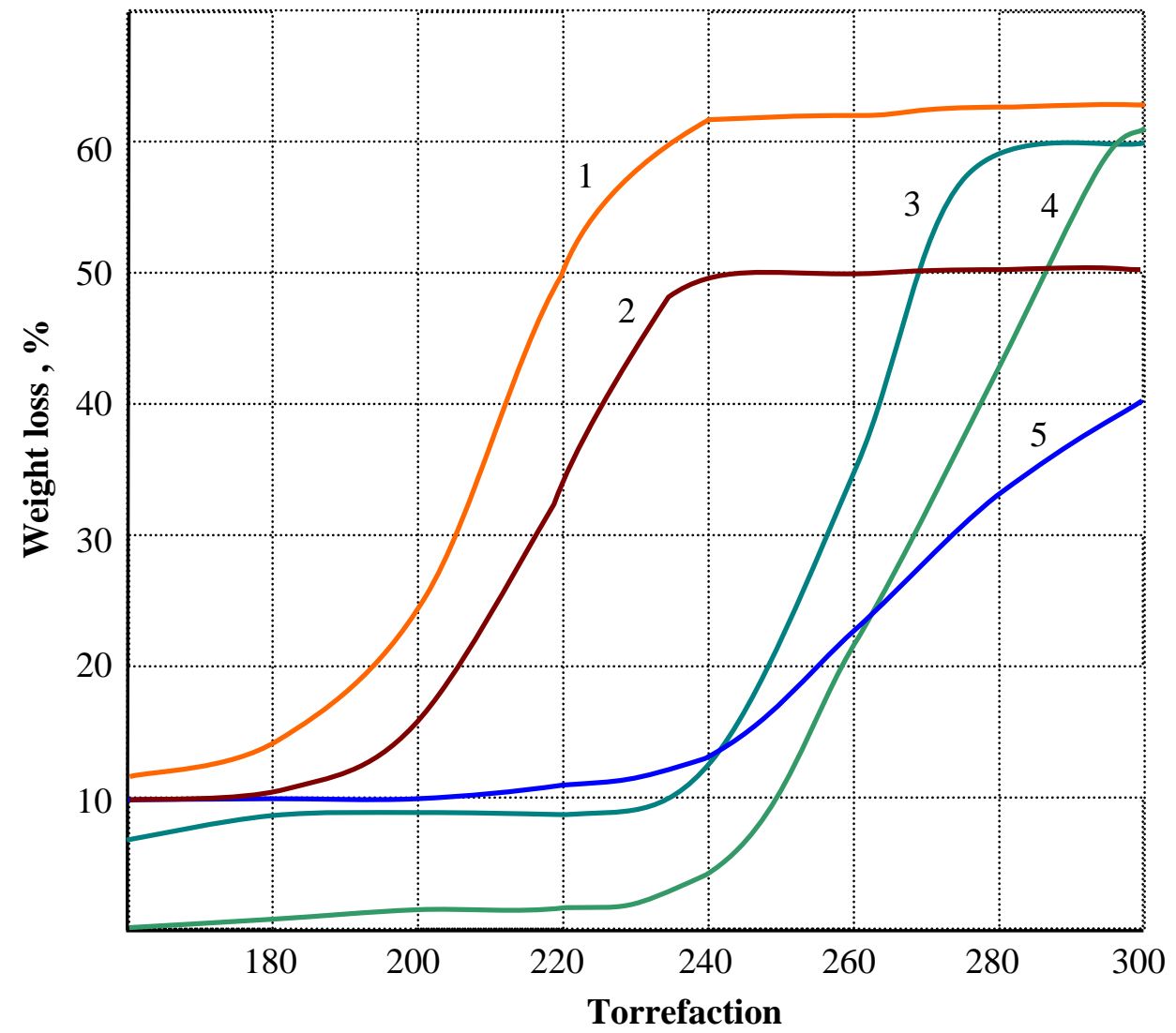

Fig. 2. Graph of the dependence of biomass weight loss on the torrefaction temperature:

1 - barley (straw) $w_{0}=13 \% ; 2-$ soybeans (chaff) $w_{0}=0 \% ; 3-$ poplar $w_{0}=6.5 \%$; $4-$ miscanthus (stems) $w_{0}=10 \% ; 5-$ willow $w_{0}=0 \%$

Analyzing the graphs, we see that the dynamics of changes in the weight loss depending on the thermal treatment temperature for different biomass occurs on similar principles. At the initial stage, the curve is almost horizontal, or with a slight slope toward the growth, depending on the initial humidity 
of the material. Obviously, as in the case of the thermogravimetric curves (Fig. 2) at this stage there is removal of free moisture and drying of the material. Further, there is a sharp increase in the weight loss, which is apparently due to the internal destruction of organic matter of biomass and the removal of volatile substances. After some period of temperature, the curve stabilizes again, which indicates the end of the active phase of thermal transformations. This interval can be considered as temperature modes of torrefaction. As it can be seen from the graphs, this interval has different values for different crops, but given that their definition does not require complex techniques and expensive equipment, this method can be a way of initial assessment of the parameters of torrefaction and the quality of torrefaction.

In addition, as a result of the research, some pattern of colour change of biomass, which is subjected to thermal treatment was noticed. The colour of the feedstock is an intuitive indicator that changes when the feedstock is thermally degraded [31]. The colour change of biomass depends on the conditions of torrefaction. It has been found that the colour change of biomass from brown to black occurs at the temperature range of $150-300{ }^{\circ} \mathrm{C}$ [32]. This primarily results from the changes in the chemical composition after torrefaction. The colour range of samples prepared at different temperatures also has its own characteristics. In most cases, there were two characteristic changes in colour. At low temperatures, characteristic mainly for the first stage of thermal treatment (Fig. 2), there is a slight change in colour towards darkening, or there is a characteristic shade. At temperatures, corresponding to the beginning of a sharp increase in the weight loss, brown-black tones appear in the samples, until they acquire a charcoal colour (Fig. 3). Since these changes correspond quite accurately to the stages described above on the curves of the weight loss, we can conclude that colour is another promising area for determining the parameters of thermal treatment of biomass.

a)

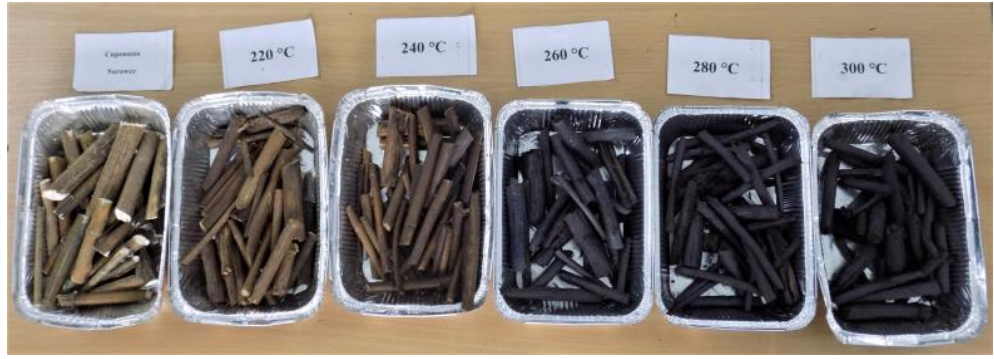

b)

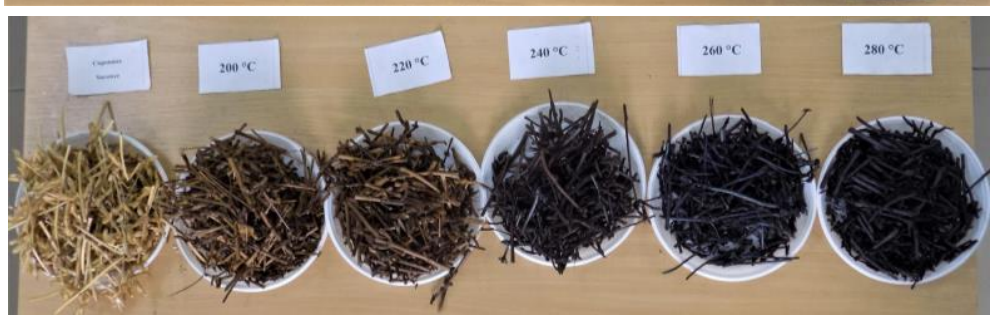

c)

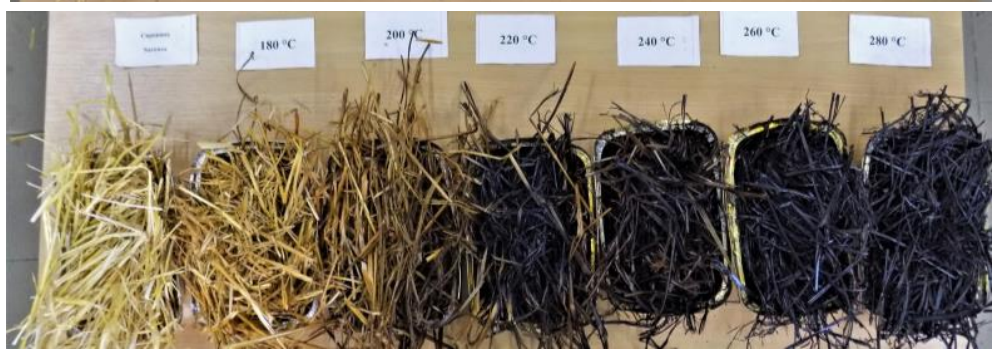

Fig. 2. Change in the colour of biomass depending on the temperature of torrefaction: $\mathrm{a}$ - Jerusalem artichoke, $\mathrm{b}$ - soybean (chaff), c - barley (straw)

\section{Conclusions}

As a result, the conducted researches proved that the torrefaction process of different raw materials meets its own temperature range, in which there are active changes of the material, namely, it converts raw biomass into a torrefied product. This range for the studied samples is $40-50{ }^{\circ} \mathrm{C}$, in particular for barley and soybeans the process of torrefaction begins at $185-195^{\circ} \mathrm{C}$ and ends at $230-240{ }^{\circ} \mathrm{C}$, for poplar, willow and miscanthus these figures are respectively $235-245^{\circ} \mathrm{C}$ and $280-300{ }^{\circ} \mathrm{C}$. 
As shown by the studies for most biomaterials of plant origin, we can distinguish the beginning of intensive transformation and its end, after which there is a sharp slowdown in the weight loss, and, accordingly, in the energy density of the samples. At the same time, there is also a parallel change in the colour of the material from darkening or discoloration to the acquisition of a charcoal colour. These changes are followed by a similar pattern as in the analysis of the weight loss curves.

Thus, the control of weight loss and discoloration of biomass subjected to thermal treatment can be parameters of the initial assessment of the modes of torrefaction and the quality of torrefaction. And this, in turn, will allow without the presence of complex equipment in the production environment with sufficient accuracy to determine the necessary modes of torrefaction.

\section{References}

[1] Енергетична стратегії України на період до 2035 року "Безпека, енергоефективність, конкурентоспроможність" (Energy Strategy of Ukraine for the period up to 2035 "Security, energy efficiency, competitiveness"). 18.08.2017. No. 605-p (In Ukrainian).

[2] Єрмаков С.В. Перспективи удосконалення конструкцій для садіння живців енергетичних культур. (Perspectives of improvement of constructions for energy crop planting) Bulletin of State Agrarian and Engineering University in Podilya V. 2 (26), 2017. pp. 37-45. (In Ukrainian).

[3] Hutsol T., Yermakov S., Firman Ju., Duganets V., Bodnar A. Analysis of technical solutions of planting machines, which can be used in planting energy willow. Renewable Energy Sources: Engineering, Technology, Innovation. 2018. pp. 99-111.

[4] Yermakov S., Hutsol T., Slobodian S., Komarnitskyi S., Tysh M. Possibility of using automation tools for planting of the energy willow cuttings. Renewable Energy Sources: Engineering, Technology, Innovation. 2018. pp. 419-429.

[5] Yermakov S., Mudryk K., Hutsol T., Dziedzic K., Mykhailova L. The analysis of stochastic processes in unloadingthe energywillow cuttings from the hopper. Environment. Technology. Resources. Rezekne, Latvia. Proceedings of the 12th International Scientific and Practical Conference. Volume III. 2019. pp. 249-252, DOI: 10.17770/etr2019vol3.4159.

[6] Сафин Р.Р., Ахунова Л.В., Тимербаева А.Л., Зиатдинов Р.Р. Химизм процесса торрефикации древесного топлива (Chemistry of the wood fuel torrefaction process). Вестник Казанского технологического университета (Kazan Technological University Bulletin), vol. 18, no. 14, 2015, pp. 148-151. (In Russian).

[7] Bui H-H, Tran K-Q, Chen W-H. Pyrolysis of microalgae residues - A Kinetic study. Bioresource Technology 2015;199, pp. 362-366.

[8] Nunes LJR, Matias JCO, Catalão JPS. A review on torrefied biomass pellets as a sustainable alternative to coal in power generation. Renewable and Sustainable Energy Reviews 2014;40:15360.

[9] Eseyin AE, Steele PH, Pittman Jr. CU. Current Trends in the Production and Applications of Torrefied Wood/Biomass - A Review 2015.

[10] van der Stelt MJC, Gerhauser H, Kiel JHA, Ptasinski KJ. Biomass upgrading by torrefaction for the production of biofuels: A review. Biomass and Bioenergy 2011;35, pp. 3748-3762.

[11] Chew JJ, Doshi V. Recent advances in biomass pretreatment - Torrefaction fundamentals and technology. Renewable and Sustainable Energy Reviews 2011;15, pp. 4212-4222

[12] Szufa S, Piersa P, Adrian Ł, Czerwińska J, Lewandowski A, Lewandowska W, Sielski J, Dzikuć M, Wróbel M, Jewiarz M, Knapczyk A. Sustainable Drying and Torrefaction Processes of Miscanthus for Use as a Pelletized Solid Biofuel and Biocarbon-Carrier for Fertilizers. Molecules. 2021; 26(4):1014. DOI: 10.3390/molecules26041014

[13] Wróbel M, Jewiarz M, Mudryk K, Knapczyk A. Influence of Raw Material Drying Temperature on the Scots Pine (Pinus sylvestris L.) Biomass Agglomeration Process-A Preliminary Study. Energies. 2020; 13(7):1809. DOI: 10.3390/en13071809

[14]Зайченко В.М., Косов В.В., Синельщиков В.А. Торрефикация - способ улучшения потребительских характеристик гранулированного топлива из биомассы. (Torrefaction is a way to improve the consumer characteristics of pelleted biomass fuel.). Energy technologies and resource conservation. 2012. № 5. pp. 37-41 (In Russian). 
[15] Gan YY, Ong HC, Show PL, Ling TC, Chen W-H, Yu KL, et al. Torrefaction of microalgal biochar as potential coal fuel and application as bio-adsorbent. Energy Conversion and Management 2018;165, pp. 152-62.

[16] Pilon G, Lavoie J-M. Characterization of switchgrass char produced in torrefaction and pyrolysis conditions. 2011. 2011;6:16.

[17] Prins MJ, Ptasinski KJ, Janssen FJ. Torrefaction of wood, pp. Part 1. Weight loss kinetics. Journal of analytical and applied pyrolysis. 2006;77, pp. 28-34.

[18] Chen W-H, Kuo P-C. Isothermal torrefaction kinetics of hemicellulose, cellulose, lignin and xylan using thermogravimetric analysis. Energy 2011;36, pp. 6451-60.

[19] Bates RB, Ghoniem AF. Biomass torrefaction, pp. Modeling of volatile and solid product evolution kinetics. Bioresource Technology 2012;124, pp. 460-9.

[20] Bach Q-V, Chen W-H, Chu Y-S, Ø Skreiberg. Predictions of biochar yield and elemental composition during torrefaction of forest residues. Bioresource Technology 2016;215, pp. 239-46.

[21] Марьяндышев П.А., Попова Е.И., Чернов А.А., Любов В.К. Изотермическое исследование древесного топлива и его органических копонентов (Isothermal study of wood fuel and its organic components. Resource saving.). Вестник Череповецкого государственного университета (Bulletin of the Cherepovets State University), № 2 (71), 2016, pp. 15-18. (In Russian).

[22] Jankovich Z.B, Jankovich M.M. Pyrolysis of pine and beech woodsamples under isothermal experimental conditions. The determination of kinetic Cellulose Chemistry and Technology, 2013, Vol.47, pp. 681-697

[23] Ivanyshyn V., Yermakov S., Ishchenko T. etc. Calculation algorithm for the dynamic coefficient of vibro-viscosity and other properties of energy willow cuttings movement in terms of their unloading from the tanker. Proceedings of 6 th International Conference - Renewable Energy Sources, vol. 154, E3S Web of Conferences. 2020. pp. 04005. DOI: 10.1051/e3sconf/202015404005

[24] Yermakov S., Hutsol T., Ovcharuk O., Kolosiuk I. Mathematic simulation of cutting unloading from the bunker. Independent journal of management \& amp; production (IJM\&P). Vol. 10, No. 7. 2019. pp. 758-777

[25] Korchak M., Yermakov S., Maisus V. etc. Problems of field contamination when growing energy corn as monoculture. Proceedings of 6 th International Conference - Renewable Energy Sources, vol. 154, E3S Web of Conferences. 2020. pp. 01009 DOI: 10.1051/e3sconf/202015401009

[26] Tryhuba A., Hutsol T., Glowacki S. etc. Forecasting Quantitative Risk Indicators of Investors in Projects of Biohydrogen Production from Agricultural Raw Materials. Processes 2021, 9, 258. DOI: 10.3390/pr9020258

[27] Tryhuba A, Hutsol T, Tryhuba I etc. Risk Assessment of Investments in Projects of Production of Raw Materials for Bioethanol. Processes. 2021; 9(1):12. DOI: 10.3390/pr9010012

[28] Любов В.К., Попова Е.И., Шкаева Н.В., Болотова К.С., Солнышкова Л.М. Исследование процесса торрефикации древесины. (Research of the process of wood torrefaction.) Вестник Череповецкого государственного университета (Bulletin of the Cherepovets State University), №3 (78), 2017, 38-45. (In Russian).

[29] Ermochenkov M.G. Kinetika termicheskoy destruktsyi drevesiny v srede inertnyh gazov [Kinetics of thermal degradation of wood in inert gases]. Tehnologiya $\mathrm{i}$ oborudovanie dlya pererabotki drevesiny [Scientific works], 2014, no. 370, pp. 113-118. (In Russian).

[30] Серков Б.Б., Сивенков А.Б., Тхань Б.Д., Асеева Р. М. Термическое разложение древесины тропических пород (Thermal decomposition of tropical wood). Лесной вестникю (Forestry bulletin), 38 (2), 2005, pp. 70-76. (In Russian).

[31]González-Peña MM, Hale MDC. Rapid assessment of physical properties and chemical composition of thermally modified wood by mid-infrared spectroscopy. Wood Science and Technology 2010;45, pp. 83-102

[32] Shankar Tumuluru J, Sokhansanj S, Hess JR, Wright CT, Boardman RD. A review on biomass torrefaction process and product properties for energy applications. Industrial Biotechnology 2011;7, pp. 384-401. 